\title{
Improvement of Biological Productivity in Degraded Lands in Thailand II. Influences of Soil Temperature, Moisture, and Fertility on Plant Growth in the Takuapa Experimental Site
}

\author{
Katsutoshi SAKURAI Faculty of Agriculture, Kochi University, Nankoku 783, Japan \\ Buared PRACHAIYO Regional Forest Division, Royal Forest Department, Kon Kaen 40000, Thailand \\ Tasnee ATTANANDANA Department of Soil Science, Kasetsart University, Bangkok 10903, Thailand \\ Virat TANPIBAL Department of Land Development, Bangkok 10900, Thailand \\ Sigeru ARAKI Center for African Area Studies, Kyoto University, Sakyo-ku, Kyoto 606, Japan \\ Takahiko NAGANAWA Faculty of Agriculture, Shimane University, Matsue 690, Japan \\ Goro IWATSUBO Faculty of Agriculture, Kyoto University, Sakyo-ku, Kyoto 606, Japan \\ Kyoji YODA \\ Faculty of Science, Osaka City University, Sumiyoshi-ku, Osaka 558, Japan
}

\begin{abstract}
On the sand and gravel tailings after tin mining in Takuapa, Phang-nga province, Thailand, Eucalyptus camaldulensis was planted mainly for rehabilitation of the degraded land, and cassava and pineapple were cultivated for demonstrating the possible way of agriculture. This work is a part of "Waste Land Project" (WLP), having been conducted in Thailand for six years.

Mulching among others was considered to be the best treatment for both trees and crops based on the following reasons, i) mulching lowered the maximum soil temperature in the hottest period, ii) it kept a good moisture condition throughout the year, iii) mulching materials could be utilized by plants as a source of nutrients as well as enhanced biological activity, and iv) they could be practiced easily, using weeds collectible in situ.

As far as rehabilitation of a barren land is mainly concerned, Eucalyptus camaldulensis combined with Imperata mulching proved to be most promising. On the other hand, in order to establish a practical approach to agriculture under the severely poor soil conditions encountered, further exertion is indispensable for the goal, i.e., a reasonable, at least, sustainable yield of cassava and pineapple.
\end{abstract}

Key Words: degraded land / Eucalyptus camaldulensis / soil conditions / Thailand / Waste Land Project

Concession of the tin mining is concentrated on the western coastal area of the peninsular Thailand, especially in high density in Phang-nga province. Total concession and abandoned areas in 1987 were 671 and $480 \mathrm{~km}^{2}$, respectively, and covered altogether $0.22 \%$ of the total land area of Thailand (Tanpibal \& Sahunalu, 1989). Most tin ores are found in alluvial deposits and mining operations by the two methods used, employ water for the mechanical separation of tin ore from the tin-bearing earth. This results in the deposit being separated into sand, clay, gravel, and their mixture in various composition. Among them, the sand depositional area occupies more than $80 \%$ of the total area (Tanpibal \& Sahunalu, 1989). Vegetational cover after mining is quite sparse except for a few species, i.e., Casuarina equisetifolia trees on the sand deposit and Imperata cylindrica grassland on the clay deposit.

At a glance, there is nothing established on the land surface of the gravel tailings. Natural 


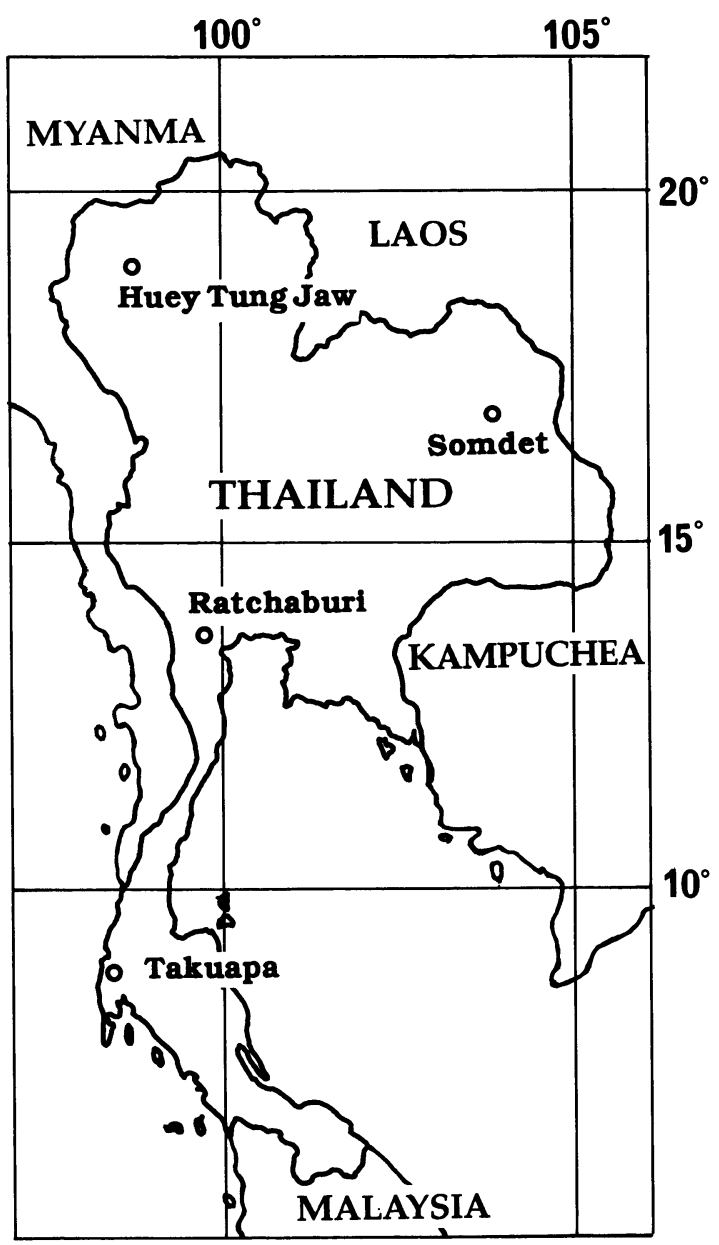

Fig. 1. Study sites.

Cited from Sakurai et al, 1989 (modefied).

regeneration of any plant species seems to be quite difficult, and therefore, utilization of this degraded land is far from the concern of farmers. In 1968, in order to restore the vegetational cover, the Department of Land Development established a Tin Mine Spoil Research Station. This station has conducted experiments concerning the utilization of tin mine tailings aiming at reforestation and agriculture, including fodder grass screening, cashew tree and cantaloupe trials with or without chemical fertilizer and city compost. Forest tree species trials have also been conducted (Tanpibal \& Sahunalu, 1989). The major objective of the present work is to ensure a more intensive and efficient promotion of the various projects already set in motion.

\section{STUDY SITE AND ANALYTICAL METHODS}

\section{Description of the Experimental Plots}

Inside the Forestry Student's Training Station of Kasetsart University in Takuapa, Phang-nga province, situated $10 \mathrm{~km}$ west of Takuapa city and close to the Andaman Sea, a study site was established on the land after pump mining of more than twenty years (Fig. 1). After the reconnaissance in 1984, an experimental plot of 1.3 ha was demarcated in 1985, on a small fan-shaped sand and gravel tailing area, slightly sloping to the northwest (Fig. 2). Climatologically, Takuapa region belongs to Köppen's Am (Thailand Development Research 




Fig. 2. Design of Takuapa experimental site.

Institute, 1987). The approximate altitude of the experimental site is $10 \mathrm{~m}$ above sea level.

Since soil profile description and physical properties in this experimental site have been shown elsewhere (Sakurai et al., 1989), a brief description of the site will be given below. In this site, gravel and sand layers appeared alternately throughout the soil profile, though at the very limited parts of the solum, thin clayey layers (less than $2 \mathrm{~mm}$ in thickness) were observed. Thus, these materials showed a very low water holding capacity and a hydraulic conductivity faster than $3 \times 10^{-2}(\mathrm{~cm} / \mathrm{sec})$. Sahunalu \& Anunsiriwat (1985) discussed the soil chemical and physical properties of seven different vegetational types of this station. They showed that the average clay content of gravel-sand tailings from three soil pits was $9 \%$. However, in our experimental site, clay content was less than $2 \%$.

\section{Experimental Design}

The layout of the experimental plots is shown in Fig. 2. Eight silvicultural plots and nine agronomic plots are summarized in Table 1 together with the treatments and their cost.

Silvicultural plots. Eucalyptus camaldulensis was selected out of several tree species based on the result obtained by Tanpibal \& Sahunalu (1985), and planted in $2 \mathrm{~m} \times 2 \mathrm{~m}$ planting space, in May, 1985. TE-01 was designated as a control plot without any treatment before planting. TE-02 had been a control plot for 1 and half years after transplanting of the seedlings, until mulching treatment was initiated from December, 1986, using fresh grasses (Imperata sp.) collected from the abandoned local area near our experimental site. Mulching was conducted at the rate of 1 ton/plot (16.7 tons ha-1), once a year, usually in December or January.

Plowing (TE-1 to TE-6) was carried out by hand hoe three times a year, usually in April, September, and November. Chemical fertilizer (15:15:15) was applied 3 times a year in TE-2 
Table 1. Treatment and cost of each plot .

Silivicultural plots (Eucalyptus camaldulensis)

\begin{tabular}{|c|c|c|c|c|c|c|c|c|c|}
\hline Plot & $\begin{array}{c}\text { Area } \\
\mathrm{m}^{2}\end{array}$ & Plowing & $\mathrm{CF}^{* *}$ & $\begin{array}{l}\text { Compost } \\
-(t / h a)\end{array}$ & Mulch & $\begin{array}{c}\text { Cost } \\
\text { Bahts/ha }\end{array}$ & $\begin{array}{l}\text { Max. } \\
\text { Yield } \\
\text { kg/ha }\end{array}$ & $\begin{array}{l}\text { Max. } \\
\text { Income } \\
\text { Bahts/ha }\end{array}$ & Remarks \\
\hline TE-01 & 600 & - & - & - & - & - & & & \\
\hline TE-02 & do. & - & - & - & 16.7 & 16,700 & & & $1.00 \$=25.5$ Bahts \\
\hline TE-1 & do. & May & 一 & 一 & - & 一 & & & \\
\hline TE-2 & do. & do. & 1.67 & - & - & 10,020 & & & \\
\hline TE-3 & do. & do. & do. & 12.5 & - & 28,770 & & & \\
\hline TE-4 & do. & do. & do. & do. & - & 28,770 & & & Clayey material dressing \\
\hline TE-5 & do. & do. & do. & 一 & 一 & - & 2,008 & $3,020^{*}$ & Pineapple intercroping \\
\hline TE-6 & do. & do. & do. & - & - & - & & & $\begin{array}{l}\text { Cover plant } \\
\text { (Stylosanthes hamata) }\end{array}$ \\
\hline
\end{tabular}

Agronomic plots (TC:Cassava, TP:Pineapple)

\begin{tabular}{|c|c|c|c|c|c|c|c|c|c|}
\hline Plot & $\begin{array}{c}\text { Area } \\
\mathrm{m}^{2}\end{array}$ & Plowing & $\mathrm{CF}^{* *}$ & $\begin{array}{l}\text { Compost } \\
-(\mathrm{t} / \mathrm{ha})\end{array}$ & Mulch & $\begin{array}{c}\text { Cost } \\
\text { Bahts/ha }\end{array}$ & $\begin{array}{l}\text { Max. } \\
\text { Yield } \\
\text { kg/ha }\end{array}$ & $\begin{array}{l}\text { Max. } \\
\text { Income } \\
\text { Bahts/ha }\end{array}$ & Remarks \\
\hline TC-0 & 125 & - & - & - & - & - & - & - & \\
\hline $\mathrm{TC}-0 \mathrm{~m}$ & do. & - & - & - & 36 & 36,000 & 2,350 & $1,495^{*}$ & \\
\hline TC-1 & 250 & May & 4 & 24 & 一 & 60,000 & 17,110 & $10,882^{*}$ & \\
\hline TC-2 & do. & do. & 4 & 24 & 36 & 96,000 & 26,420 & $16,803^{*}$ & \\
\hline TC-3 & do. & do. & 4 & 一 & 36 & 60,000 & 11,910 & $7,575^{*}$ & \\
\hline TP-0 & do. & do. & - & - & - & - & 320 & $481^{*}$ & \\
\hline TP-1 & do. & do. & 4 & 24 & - & 60,000 & 10,724 & $16,129^{*}$ & \\
\hline TP-2 & do. & do. & 4 & 24 & 36 & 96,000 & 23,716 & $35,669^{*}$ & \\
\hline TP-3 & do. & do. & 4 & - & 36 & 60,000 & 16,180 & $24,335^{*}$ & \\
\hline
\end{tabular}

*: Average farm prices from 1980 to 1989 were used for calculation, 1.504 Bahts $/ \mathrm{kg}$ for pineapple, and 0.636 Bahts/kg for cassava (according to Office of Agricultural Economics, 1990).

**: Chemical Fertilizer.

-: Not applied.

to TE-6; $30 \mathrm{~kg} /$ plot in April, $35 \mathrm{~kg} /$ plot in September and $35 \mathrm{~kg} / \mathrm{plot}$ in November, totalling $100 \mathrm{~kg} /$ plot $\left(1.67\right.$ tons ha $\left.^{-1}\right)$. City compost (Bangkok, No.1) of total $750 \mathrm{~kg} / \mathrm{plot}\left(12.5\right.$ tons ha $\left.^{-1}\right)$ a year was applied in TE-3 and TE-4; $300 \mathrm{~kg} / \mathrm{plot}$ in April, $200 \mathrm{~kg} / \mathrm{plot}$ in September, and 250 $\mathrm{kg} / \mathrm{plot}$ in November. Both chemical fertilizer and city compost were applied by broadcasting and mixed with the surface soil (approximately up to $10 \mathrm{~cm}$ depth) by hand hoe. However, both chemical fertilizer and city compost were applied only at the beginning of the experiment in $1 \mathrm{~m} \times 1 \mathrm{~m}$ square around the planting spot for TE-2, TE-3, TE-5, TE-6, on one hand, but in a different way for TE-4.

Original land preparation of TE-4 was as follows; $0.125 \mathrm{~m}^{3}$ of clayey materials was mixed thoroughly with $5 \mathrm{~kg}$ of compost and $0.667 \mathrm{~kg}$ of chemical fertilizer, and transferred into a box $(50 \times 50 \times 50 \mathrm{~cm}$ in size). After the box was removed from the planting spot, the land was leveled and seedlings transplanted. Accumulated clayey materials resulting from mining concession were collected close to the experimental site. These had $43 \%$ of solid ratio and 2.67 of true density, i.e., $0.125 \mathrm{~m}^{3}$ of them corresponded to $143 \mathrm{~kg}$ of oven-dried soil.

Furthermore, we had some special treatments together with Eucalypt plantation in TE-5 and TE-6, aimed at agroforestry. In TE-5, pineapple (Ananas comosus) was planted as inter- 
crop, while in TE-6, covering plants were grown. Leguminous species, Stylo grass (Stylosanthes hamata) was used to cover the land surface and to improve the degraded condition because of its nitrogen fixing ability (Tanpibal \& Sakurai, in prep.).

Agronomic plots. Cassava (Manihot esculenta) and pineapple were grown in the agronomic plots, and expressed as TC and TP, combined with the numeral representing the treatment applied (see Fig. 2 and Table 1).

Planting space and population density for cassava were $0.5 \mathrm{~m} \times 0.5 \mathrm{~m}$ and 35,520 plants ha- ${ }^{-1}$, respectively, which seemed to be a little bit too dense, compared with the experiment conducted by El-sharkawy \& Cook (1987). It was, however, equivalent to that adopted in the commercial plantation. Cassava was planted at the onset of rainy season (late April), every year and harvested on late January, i.e., growth period was nine months.

On the other hand, planting space and population density for pineapple were $0.5 \mathrm{~m} \times 0.3$ $\mathrm{m}$ with $1 \mathrm{~m}$ interval between rows, and 38,400 plants ha ${ }^{-1}$, respectively. The value of plant density seem to be moderate in reference to figures appearing elsewhere (Bartholomew \& Kadzimin, 1977). Pineapple was firstly planted on April, 1985 and harvested on Oct., 1986, and secondly planted on April, 1987 and harvested on Oct., 1988. It took eighteen months to collect fruits. Flower inducer (ETHREL, commercial products name in Thailand) was applied on April and May, 1986 for first crop, and May, 1988 for the next. Without it, yield would have been very poor under the prevailing conditions.

Both of these are important cash crops in Thailand. According to Agricultural Statistics of Thailand (Office of Agricultural Economics, 1989), cassava has been harvested mainly in 42 provinces out of 73 . This crop is said to occupy 1.62 million ha and the third most cultivated crop in the whole of Thailand, following paddy (10.35 million ha) and maize (1.84 million ha). On the other hand, pineapple is harvested in 10 provinces mainly in the central plain and its total area in Thailand is said to be 0.071 million ha. Although dominant cash crops in the Southern Thailand are perennial tree species such as cashew, rubber, oil palm, coffee, and durian (Thailand Development Research Institute, 1987), they need several years before harvest. Cassava and pineapple can be harvested within a relatively short period, thus ensuring rapid production and spread. Demonstration of the cultivation of these crops on the gravel tailings was an important purpose of our work.

For TC-1 to TC-3 and TP-1 to TP-3, chemical fertilizer (15:15:15) was applied three times a year; $30 \mathrm{~kg} / \mathrm{plot}$ in April, $35 \mathrm{~kg} / \mathrm{plot}$ in September and $35 \mathrm{~kg} / \mathrm{plot}$ in November, totalling $100 \mathrm{~kg} / \mathrm{plot}\left(4\right.$ tons ha- ${ }^{-1}$ ). City compost (Bangkok compost No.1) of $600 \mathrm{~kg} / \mathrm{plot}(24$ tons ha-1) a year was applied in TC-1, TC-2, TP-1, and TP-2, usually $200 \mathrm{~kg} / \mathrm{plot}$ in April, $200 \mathrm{~kg} / \mathrm{plot}$ in September, and $200 \mathrm{~kg} / \mathrm{plot}$ in November. Both chemical fertilizer and city compost were applied by broadcasting and mixed with the surface soil (approximately up to $10 \mathrm{~cm}$ depth) by hand hoe.

Mulching by fresh imperata grass carried out in TC-0m, TC-2, TC-3, TP-2, and TP-3 was at the rate of 36 fresh tons ha-1 year-1 $(250 \mathrm{~kg} / \mathrm{plot}$ for TC- $0 \mathrm{~m}$, and $500 \mathrm{~kg} / \mathrm{plot}$ for the others).

Analytical methods. All chemical analyses presented in this chapter were conducted in Department of Soils, Faculty of Agriculture, Kasetsart University, Thailand. Analytical items (and their abbreviation in parentheses) and methods are as follows: $\mathrm{pH}$ in water ( $\mathrm{pHw}$ ) and/or $1 \mathrm{~N}-\mathrm{KCl}(\mathrm{pHK}), 1: 5$ of soil:solution ratio; electric conductivity (EC), 1:5 of soil to 
water ratio; organic matter (OM), Walkley-Black method; total nitrogen (T-N), wet digestion and distillation; available nitrogen (Av.N), distillation by $\mathrm{N}-\mathrm{KCl}$ extract; available phosphorus (Av. P), Bray No.2 method; exchangeable cations (Ex. Ca, Ex. Mg, Ex. K, and Ex. Na), $\mathrm{N}$-ammonium acetate ( $\mathrm{pH}$ 7) extraction; cation exchange capacity (CEC), $\mathrm{N}$-ammonium acetate ( $\mathrm{pH}$ 7) method; acidity (Exchangeable hydrogen and aluminum, Ex. $\mathrm{H}$ and $\mathrm{Ex} . \mathrm{Al}$ ), $\mathrm{N}-\mathrm{KCl}$ extraction.

\section{RESULTS AND DISCUSSION}

\section{Precipitation, Air and Soil Temperature}

During June 1985 to January 1990, daily rainfall as well as maximum and minimum temperature were recorded at the experimental site. In Fig. 3, monthly precipitation and average maximum and minimum temperatures are depicted. Total precipitation in 1986 amounted to $4,721 \mathrm{~mm}$ and the average of 4 years was $3,112 \mathrm{~mm}$. Maximum temperature ranged from 30 to $48^{\circ} \mathrm{C}$ and minimum temperature ranged from 17 to $28^{\circ} \mathrm{C}$. Since the thermometer was set about $30 \mathrm{~cm}$ above the ground surface, monthly mean maximum temperature exceeded $45^{\circ} \mathrm{C}$
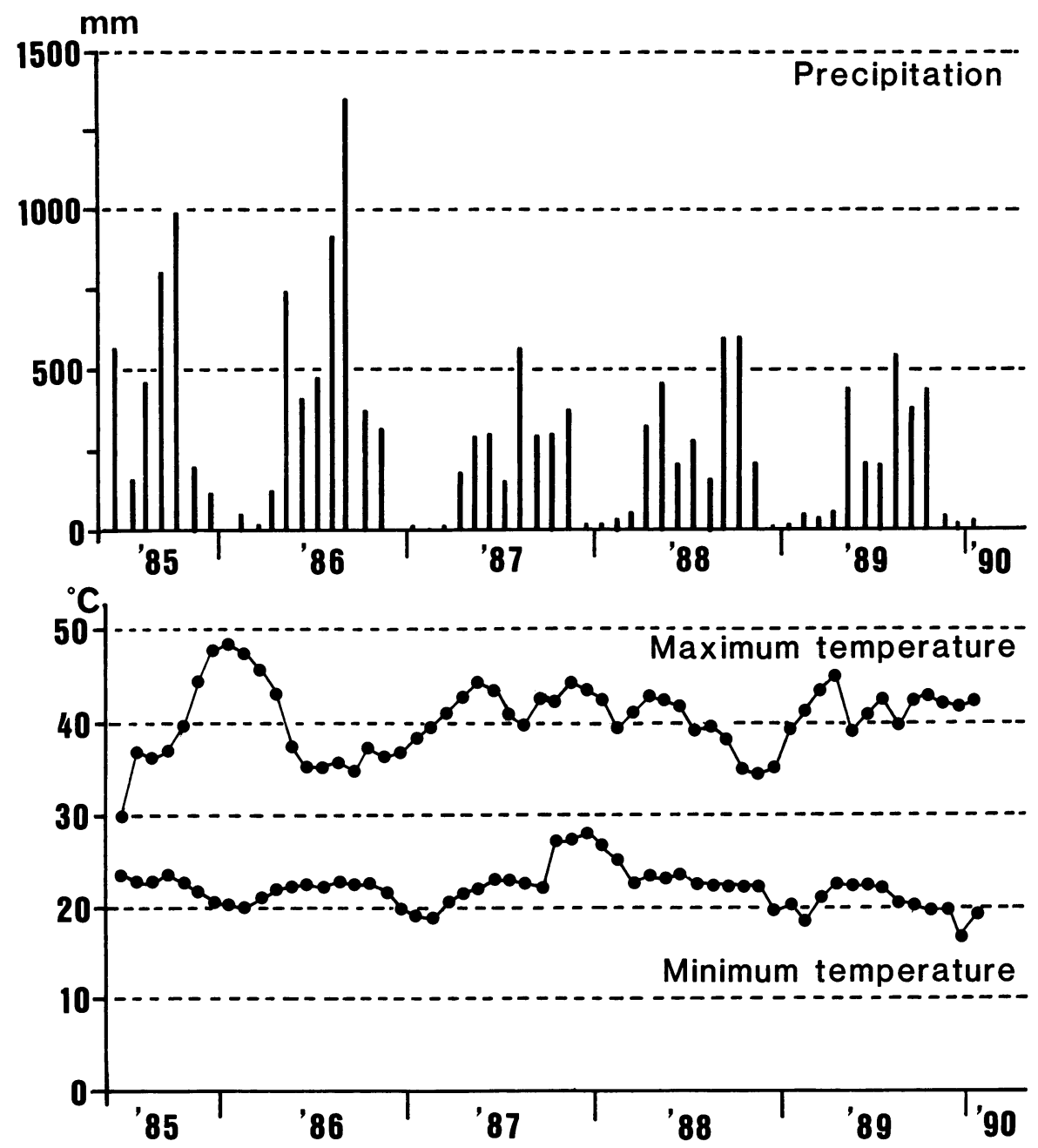

Fig. 3. Monthly precipitation and average maximum and minimum temperatures from October 1985 to January 1990. 
in several months. Temperature in summer was not always the highest within a year due to frequent and heavy rainfall. The meteological data indicated a perhumid condition in the rainy season, but an excessively hot and dry condition in the dry season. Growth of trees and crops planted might suffer from both of these extreme conditions.

Total biomass of planted trees have after 4 years in each plot and the amount (tons of dry matter ha-1) was in such a sequence (Kanzaki et al., in prep.);

TE-4 $>>$ TE- $2>$ TE- $3>$ TE- $5>$ TE- $6>$ TE- $02>$ TE- $01>$ TE- 1

\section{$\begin{array}{llllllll}44.5 & 22.2 & 22.0 & 19.4 & 14.7 & 11.2 & 1.5 & 1.4\end{array}$}

To investigate the effects of treatments applied on soil temperature, thermometers were set in four plots (control, TE-02, TE-4, and TE-6) at four depths (ground surface $(0 \mathrm{~cm}), 5,10$, and $30 \mathrm{~cm}$ ). Some of the features in these plots are as follows: i) control plot was on the bare land with little grass around, ii) TE-02 was covered with mulching materials, approximately $10 \mathrm{~mm}$ in thickness, and the tree growth in TE- 02 was less conspicuous than that in TE- 4 and TE-6, iii) in TE-6, tree growth was intermediate between TE-02 and TE-4, and growth of the Stylo grass was too poor to cover the soil surface, and iv) TE-4 shows maximum growth of the planted trees, which would possibly supply a significant shading to the soil surface. Measurements were carried out every day at 12 o'clock during October 1988 to January 1990. Fig. 3 shows the monthly mean soil temperature in control and TE- 02 , representing the highest and the lowest soil temperatures at the surface and $5 \mathrm{~cm}$-depth. Surface temperature in the dry season often attained to $50^{\circ} \mathrm{C}$ in the control plot, whereas, in TE-02, it was not more than $40^{\circ} \mathrm{C}$. Furthermore, soil temperature at $5 \mathrm{~cm}$ in TE- 02 was not greatly different from that at $10 \mathrm{~cm}$ and $30 \mathrm{~cm}$.

Lal (1974) demonstrated the effect of rice straw mulching (4 tons ha-1) in Nigeria on lowering the temperature of soils at various depths, i.e., $5,10,20 \mathrm{~cm}$. He found that, at the initial growing stage of maize, temperature differed as much as $8^{\circ} \mathrm{C}$ between mulched and unmulched plots at the $5 \mathrm{~cm}$-depth. Soil temperature fluctuation observed in TE-02 was the smallest of all, and therefore, mulching had kept a good temperature condition for roots throughout the year.

In Fig. 4, soil temperatures at $5 \mathrm{~cm}$ depth in every four plots are shown, since fine tree roots for sucking up water and nutrients actively concentrated at this depth as well as $10 \mathrm{~cm}$. As described already, TE-02 (mulching) showed lowest and TE-01 (control) showed highest temperature. On the other hand, lower soil temperature of TE-4 (exhibiting the best tree growth) as compared to TE-6 (with sparsely grown cover grass) was observed. This fact indicates that in order to reduce the solar radiation to the surface soil, tree shading would be slightly more effective than sparsely grown cover plants.

\section{Soil Moisture}

Soil moisture content was monitored for more than 5 years using gypsum block buried at the depth of 20, 40, and $60 \mathrm{~cm}$ in 5 replications. Measurement was conducted on TE-1, TE-02, TE-4, TE-6, TC- 1 and TC-2. Fig. 5 shows the example of soil moisture content in silvicultural plot at the depth of $20 \mathrm{~cm}$ in TE-02 (mulching), TE-1 (no treatment except plowing), and TE-4 (under the biggest canopy of E. camaldulensis, but at the different place where clayey materials were dressed) from October 1988 to September 1989. Vertical axis in Fig. 5 represents the resistance value of the gypsum blocks expressed in kilo-ohm. According to the laboratory measurement, resistance values of $2.8,4.6,20$, and 2000 are nearly equivalent 

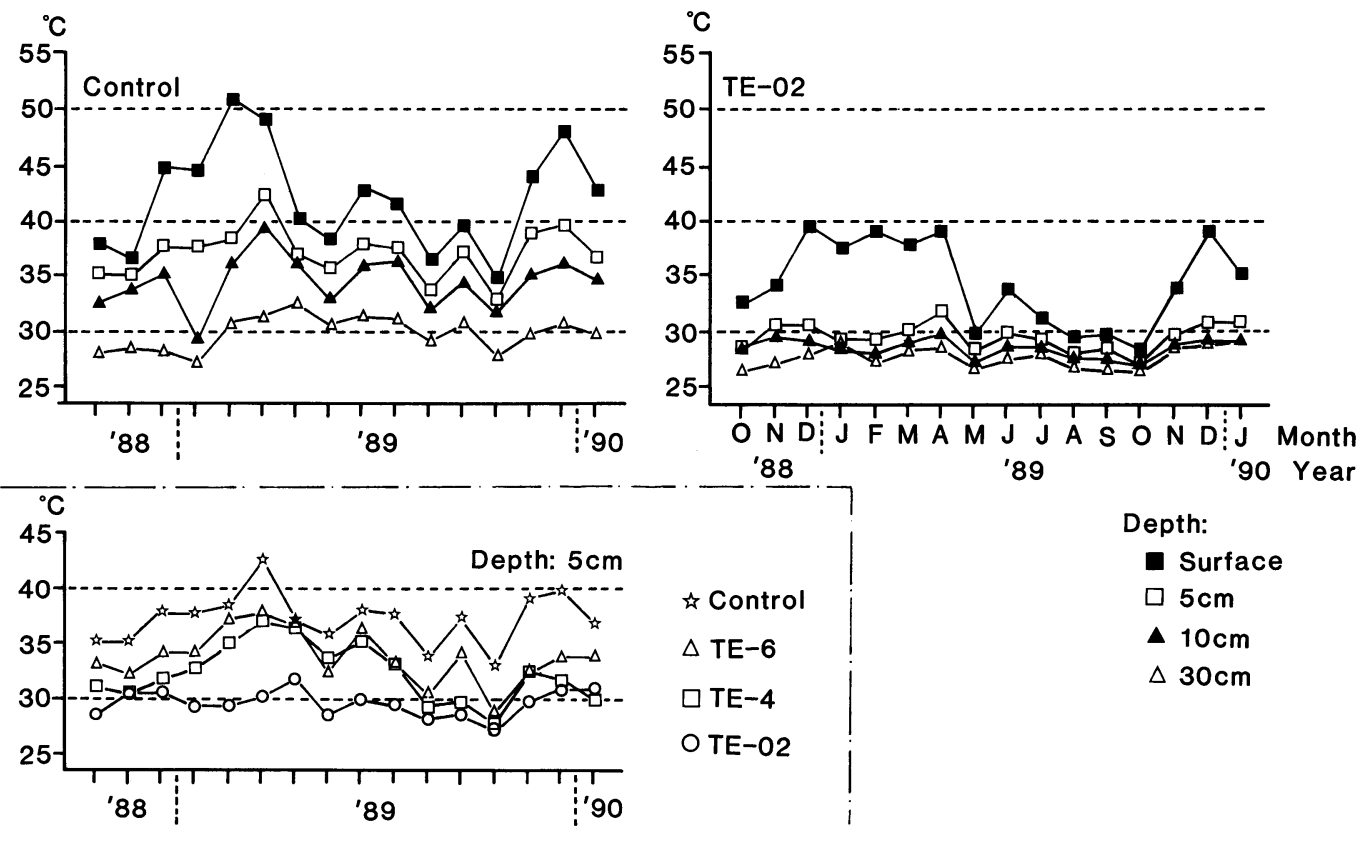

Fig. 4. Monthly mean soil temperature (Oct. 1985 to Jan. 1990). Upper: at different depths in control and TE-02. Lower: at the depth of $5 \mathrm{~cm}$ in four plots.

to $\mathrm{pF}$ values of $1.0,2.0,3.0,4.0$ for this soil, respectively. Thus, resistance value higher than 2000 may correspond to the critical moisture level for plant growth.

During rainy season, i.e., October to December, 1988 and June to September, 1989, soil moisture contents were kept below the critical level for all plots, while, they became too dry to maintain the appropriate condition for tree growth of TE-1 and TE-4, during January to May, 1989. On the other hand, in TE-02, soil moisture level was always below pF 3.0 at the depth of $20 \mathrm{~cm}$ throughout the year. In the previous section, we confirmed the effectiveness of mulching in reducing soil temperature even in the dry season in TE-02, which would be brought by the higher soil moisture content.

Lal (1974) explained that mulching at the maize field decreased evaporation losses only when the soil was at the first stage of the drying cycle. However, in this region, ground water level exists within $2 \mathrm{~m}$ even in dry season, and therefore, if mulching protect against the severe evaporation, water supply from the lower horizons would not be hindered. Thus, it can be concluded that mulching is indispensable to maintainance of soil moisture.

On the other hand, TE-1 showed much poorer tree growth but maintained better moisture condition than TE-4. This result can be attributed to the difference in the amount of evapotranspiration of Eucalypt. Bigger trees need more water in soils and releases more by evapotranspiration, which would surpass direct evaporation from soil.

In Fig. 6, soil moisture content in TC-1 (no mulching) and TC-2 (mulching) is depicted. It is quite clear that mulching plot (TC-2) could keep more water than non-mulching plot (TC-1). Good moisture condition in soils will give a good yield of cassava, as will be described later.

Gypsum blocks buried in the deeper horizon (60 $\mathrm{cm}$-depth) after 2 years were damaged to some extent by the weight of the overlying soil materials, however it still maintained a 


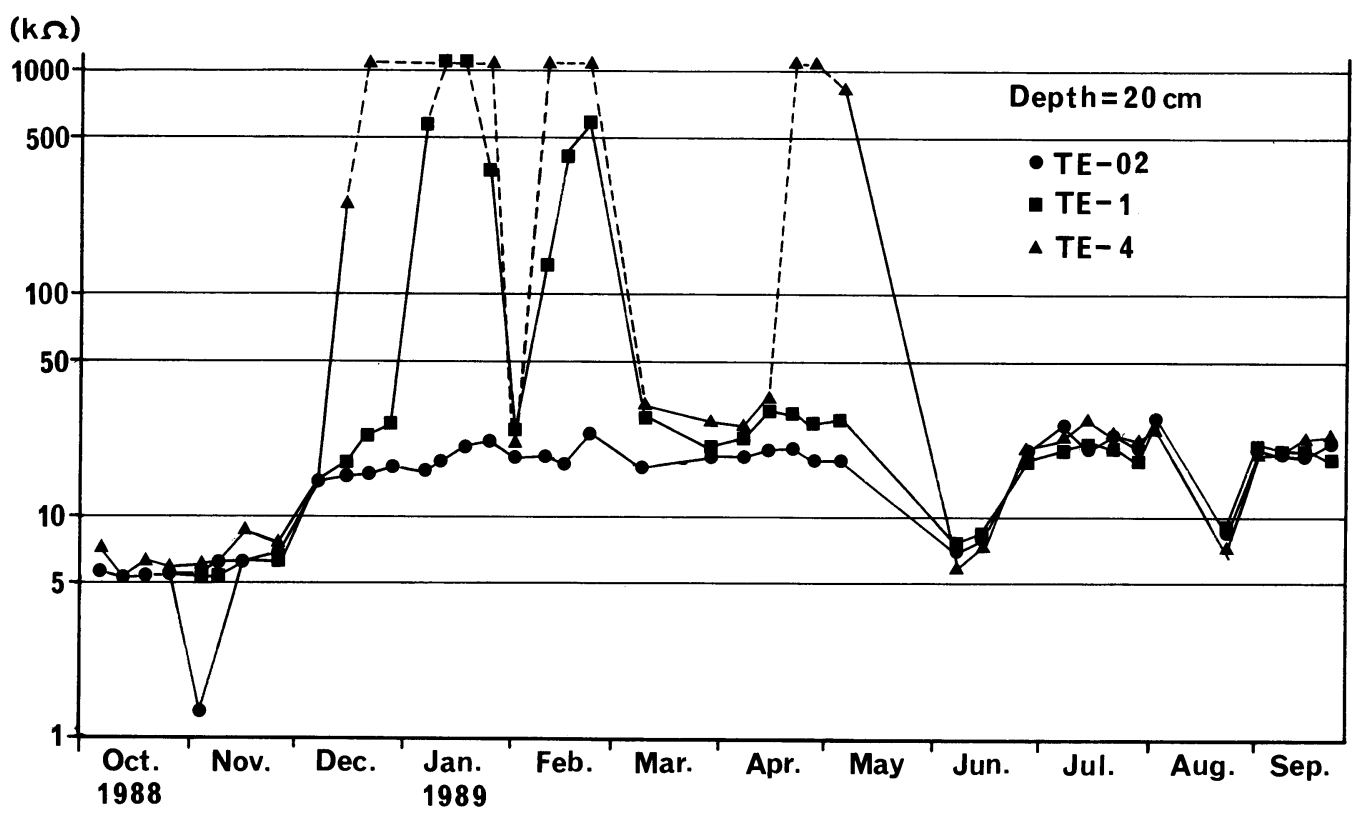

Fig. 5 Soil moisture condition monitored by gypsum blocks (1). Silvicultural plot.

reasonable quality for detection of moisture condition.

\section{Soil Moisture Tension Measured in situ}

Moisture contents of subsurface and/or surface horizons have been measured gravimetrically, and monitored by gypsum blocks. However, the level of effective water still remained unknown. Thus, in $1989, \mathrm{pF}$ value in situ was evaluated at every experimental site, using tensiometer buried at a depth of $20,40,60$ and $80 \mathrm{~cm}$. Table 2 shows these results.

Reflecting the heavy rain encountered every day during measurement, $\mathrm{pF}$ value in Takuapa Experimental Site ranged from 1.0 to 2.0 and they were quite low compared with the other sites. Generally, lower horizons showed higher $\mathrm{pF}$ values representing lower moisture content. It can be inferred that lower horizons were not quickly affected by the daily rainfall, and therefore, showed different tendency from the upper horizons.

\section{Changes in Soil Chemical \\ Characteristics}

Sample collection for analysis was conducted at least twice a year, usually, before and after soil treatment on every year. It was true that analytical value for the samples collected just after compost and chemical fertilizer

Table 2. Changes in $\mathrm{pF}$ condition measured in situ.

\begin{tabular}{llcccc}
\hline Plot & $\begin{array}{l}\text { Days } \\
\text { after } \\
\text { setting }\end{array}$ & 20 & \multicolumn{4}{c}{ Depth (cm) } \\
\hline TE-02 & 1 & 1.29 & 1.20 & 1.37 & 1.57 \\
& 2 & 1.23 & 1.23 & 1.46 & 1.39 \\
& 3 & 1.03 & 1.55 & 1.73 & 1.41 \\
& 4 & 1.69 & 1.71 & 1.87 & 1.88 \\
& 5 & 1.63 & 1.26 & - & 1.83 \\
TE-1 & 1 & 1.09 & 1.47 & 1.51 & 1.65 \\
& 2 & - & 1.54 & 1.57 & 1.65 \\
& 3 & - & 1.23 & - & 1.49 \\
& 4 & - & 1.81 & - & 1.59 \\
& 5 & - & 1.67 & 1.84 & 1.93 \\
TE-4 & 1 & 1.32 & 1.32 & 1.29 & 1.51 \\
& 2 & 1.49 & 1.54 & 1.35 & 1.72 \\
& 3 & 1.58 & 1.37 & 1.27 & 1.49 \\
& 4 & 1.73 & 1.79 & 1.71 & 1.42 \\
& 5 & 1.63 & 1.85 & 1.69 & 1.91 \\
\hline & \multicolumn{5}{c}{- not measured }
\end{tabular}




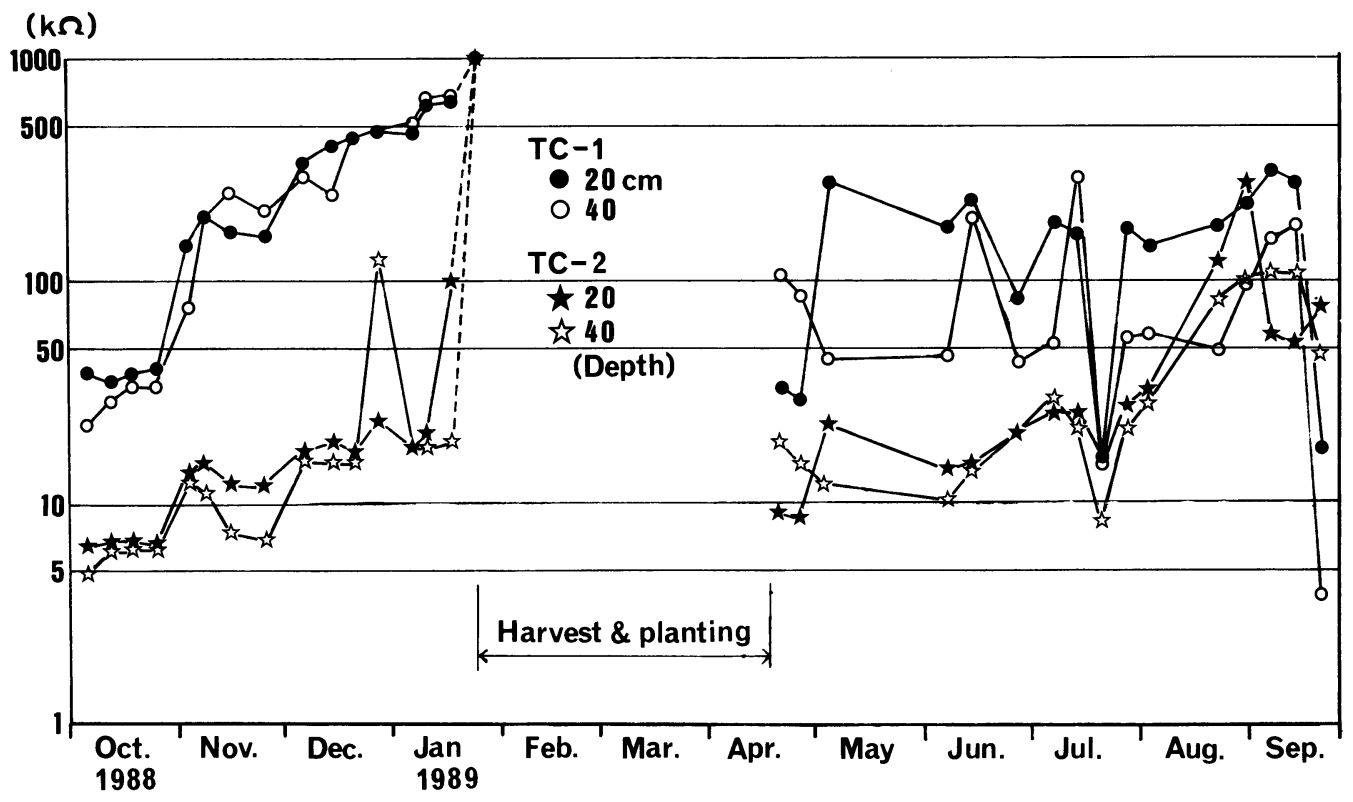

Fig. 6. Soil moisture condition monitored by gypsum blocks (2). Agronomic plot.

application showed a sharp increase in organic matter content for the former and nitrogen, phosphate, and potassium content for the latter, though the observed increase was not persistent. Analytical results at the initial condition (average value) and after 48 months experiment are summarized in Table 3. Some of the outstanding feature will be described below.

Silvicultural plots. The value of $\mathrm{pHw}$ was around 5.0 in the surface soil, and ranged from 4.5 to 5.0 in the subsurface. Application of compost increased $\mathrm{pH}$ values to beyond 6.0 and 7.0 for surface and subsurface soils, respectively. Fluctuation in $\mathrm{pHw}$ was significant, especially after application of compost and/or chemical fertilizer. The former increased the $\mathrm{pHw}$, and the latter decreased it.

Originally, organic matter content was quite low. However, at the end of the 4-year-treatment, it increased in the surface soils almost on every plot. In TE- 02 , mulching materials (Imperata grass) was not likely to be left in the soil more abundantly than the compost (TE-3 and TE-4) as a source of organic matter. In the field observation, compost was not decomposed, but existed as discrete particles in soils for a long time. On the other hand, in TE-02, soil color itself changed and a lot of macro fauna (mainly earthworm) were found in surface $10 \mathrm{~cm}$. Furthermore, though this was not reflected on the analytical result of $\mathrm{OM}$, mulching seemed quite effective to increase biological activity in soils.

In addition, total nitrogen (T-N), available phosphate (Av. P), sum of exchangeable bases (Ex. B) increased significantly in TE-3 and TE-4, where both compost and chemical fertilizer were applied. On the other hand, without application of chemical fertilizer, there was no increase in Av.P in TE-02.

Soils in Takuapa showed a quite low soil fertility. Above all, OM content is extremely low. In this sense, only OM application like compost and mulching could change the soil fertility. Among them, mulching was most promising to enhance the biological activity, which is one of the most important factors to make a good soil (Syers \& Springett, 1984).

Agronomic plots. A similar tendency was recognized as in the silvicultural plots. Since 
Table 3. Soil fertility at the initial condition (average value) and after 48 months. Silvicultural plots

\begin{tabular}{llcrrrrrrrr}
\hline & & Initial & \multicolumn{8}{c}{ Eucalyptus camaldulensis (after 48 months ) } \\
& & condition & TE-01 & TE-02 & TE-1 & TE-2 & TE-3 & TE-4 & TE-5 & TE-6 \\
\hline pH & Upper & 5.2 & 5.1 & 5.5 & 5.2 & 4.8 & 6.7 & 6.2 & 4.8 & 4.9 \\
& Lower & 5.1 & 5.2 & 5.4 & 5.2 & 4.8 & 6.9 & 4.9 & 5.1 & 4.6 \\
Organic & Upper & 0.09 & 0.3 & 0.6 & 0.1 & 0.5 & 1.7 & 1.0 & 0.2 & 0.4 \\
matter(\%) & Lower & 0.03 & 0.1 & 0.1 & 0.1 & 0.2 & 0.4 & 0.2 & 0.1 & 0.1 \\
T-N & Upper & 67 & 123 & 210 & 70 & 158 & 770 & 408 & 70 & 158 \\
(ppm) & Lower & 18 & 35 & 35 & 175 & 70 & 158 & 70 & 35 & 35 \\
Av.N & Upper & 14 & 7 & 14 & 7 & 14 & 28 & 21 & 14 & 14 \\
(ppm) & Lower & 14 & 7 & 7 & 14 & 7 & 0 & 14 & 0 & 7 \\
Av.P & Upper & 4 & 2 & 4 & 2 & 36 & 382 & 193 & 23 & 49 \\
(ppm) & Lower & 3 & 1 & 1 & 2 & 26 & 52 & 16 & 12 & 20 \\
Ex.K & Upper & 10 & 30 & 60 & 25 & 25 & 40 & 30 & 25 & 30 \\
(ppm) & Lower & 10 & 20 & 20 & 20 & 20 & 25 & 20 & 140 & 20 \\
Ex.B & Upper & 0.24 & 0.38 & 0.49 & 0.26 & 0.22 & 4.44 & 3.84 & 0.35 & 0.43 \\
(meq/100g) Lower & 0.24 & 0.31 & 0.26 & 0.29 & 0.21 & 1.44 & 0.51 & 0.85 & 0.22 \\
\hline
\end{tabular}

Agronomic plots (cassava and pineapple)

\begin{tabular}{|c|c|c|c|c|c|c|c|c|c|c|c|}
\hline & & & Cassav & & & & & Pineap & & & \\
\hline & & nitial & & After 57 & 7 month & & & & After 30 & 0 month & \\
\hline & & adition & TC-0 & TC-Om & TC-1 & TC-2 & TC-3 & TP-0 & TP-1 & TP-2 & TP-3 \\
\hline$\overline{\mathrm{pH}}$ & Upper & 5.2 & 6.3 & 5.4 & 7.1 & 7.0 & 4.8 & 4.8 & 7.2 & 7.0 & 4.5 \\
\hline & Lower & 5.1 & 6.3 & 6.3 & 7.0 & 6.9 & 4.9 & 5.3 & 6.8 & 6.1 & 4.9 \\
\hline Organic & Upper & 0.09 & 0.2 & 1.0 & 2.7 & 2.2 & 1.3 & 0.3 & 1.4 & 1.9 & 0.4 \\
\hline matter $(\%)$ & Lower & 0.03 & 0.1 & 0.1 & 0.1 & 1.6 & 0.3 & 0.0 & 0.1 & 0.1 & 0.1 \\
\hline T-N & Upper & 67 & 100 & 400 & 1300 & 1000 & 200 & 158 & 630 & 823 & 140 \\
\hline$(\mathrm{ppm})$ & Lower & 18 & 100 & 100 & 100 & 200 & 40 & 18 & 35 & 57 & 70 \\
\hline Av.N & Upper & 14 & 7 & 14 & 14 & 21 & 14 & 14 & 14 & 14 & 7 \\
\hline (ppm) & Lower & 14 & 14 & 14 & 14 & 21 & 14 & 28 & 14 & 0 & 7 \\
\hline Av.P & Upper & 4 & 3 & 3 & 1213 & 750 & 107 & 2 & 522 & 446 & 149 \\
\hline$(\mathrm{ppm})$ & Lower & 3 & 2 & 2 & 24 & 119 & 49 & 2 & 9 & 11 & 32 \\
\hline Ex.K & Upper & 10 & 20 & 20 & 30 & 30 & 20 & 10 & 30 & 30 & 20 \\
\hline (ppm) & Lower & 10 & 20 & 10 & 10 & 10 & 20 & 20 & 20 & 20 & 10 \\
\hline Ex.B & Upper & 0.24 & 0.34 & 0.46 & 4.47 & 3.82 & 0.47 & 0.47 & 5.07 & 7.35 & 0.33 \\
\hline$(\mathrm{meq} / 100 \mathrm{~g})$ & Lower & 0.24 & 0.37 & 0.31 & 0.59 & 0.94 & 0.60 & 0.14 & 0.38 & 0.36 & 0.25 \\
\hline
\end{tabular}

the application rate of compost and chemical fertilizer in the agronomic plots was higher than in the silvicultural plots, difference between fertilized and non-fertilized plots was greater.

Every specific value on soil fertility was higher in mulching plots (TC-1, -2, TP-1, -2) than in non-mulching (TC-1, TP-1), and non-fertilized plots (TC-0, TP-0). In TC-0m, mulching treatment was applied in addition to TC-0 (plowing only), and consequently, higher organic matter and total nitrogen content were observed in TC- $0 \mathrm{~m}$ than in TC-0. As stated before, in mulching plot under Eucalyptus, we could find abundant earthworms. However, there was no proof of earthworm activity under mulching in TE- $0 \mathrm{~m}$ probably due to the yearly plowings in preparation for new crops. Tree plantation is more favorable way of management than intensive agriculture to improve biological activity under such an extremely poor soil condition.

Among two agronomic plots, the amount of OM, T-N, and Av. P in cassava plots was more than that in pineapple plots, whereas, the other properties fluctuated in a similar manner with each other, and also to the same degree. The reason for this phenomenon would be a 
subject to study furthermore.

\section{Yield of Cassava and Pineapple}

In order to exemplify the possibility of agriculture on the gravel tailings after tin mining, cassava and pineapple were cultivated in Takuapa. Yield of cassava is summarized in Table 4. The highest yield was always obtained in TC-2, where mulching, city compost, and chemical fertilizer were applied. When chemical fertilizer was applied, mulching (TC-3) and city compost (TC-1) gave almost same effect on the cassava yield for 4 years. On the contrary, little products could be collected from the control plot, TC- 0 . However, with only mulching, (TC- $0 \mathrm{~m}$ ), the yield went up to approximately to one-fourth that of TC-3. These data indicated the effectiveness of mulching.

It is quite obvious that luxurious treatment in TC-2 gave the highest yield even under a poor soil condition both in chemical and physical properties. However, considering the economical aspect, intensive treatments conducted here were far beyond sustainable. Mulching materials such as Imperata grass can be collected easily from the local abandoned area, and therefore, promising way of approach here. Furthermore, if possible, application of chemical fertilizer at the same time will assure a reasonable produce of cassava.

In Tables 4 and 5, total biomass of cassava and pineapple is shown. Yield of cassava is represented in fresh weight basis only in 1986. Judging from another four years' data and calculating into oven-dried basis, approximately $25 \%$ of fresh weight would be equivalent to the dry weight. Accordingly, cassava dry yield of 1986 would amount to the mean of those of 1988 and 1987.

According to the Office of Agricultural Economics (1989), average cassava yield in Thailand from 1980 to 1989 was $14.96 \mathrm{t}$ fresh root $\mathrm{ha}^{-1}$. Verapattananirund et al. (1988) reported the yield of $16.6 \mathrm{t}$ fresh root ha-1 on the sandy soils in North-east Thailand, using a traditional farmers' practice of plow-harrow before planting and three hand-weeding operations during the initial stages of cassava development. Compared with their result, $21.2 \mathrm{t}$ fresh root yield ha-1 of TC-2 in 1986 showed the possibility that careful management could produce enough amounts of cassava even in far more infertile soil after mining at Takuapa in Southern Thailand. El-Sharkawy \& Cock (1987) showed the yield of $57 \mathrm{t}$ fresh root ha-1 in Colombia, using high yielding variety, CM 507-37. Introduction of a high yielding variety may enable commercial management of this crop.

Average yield of pineapple in Thailand from 1980 to 1989 was 24.17 fresh tons ha ${ }^{-1}$ (Office of Agricultural Economics, 1989), whereas, Sanchez (1976) reported the yield of 12.5 $d r y$ tons ha-1. Even at the luxurious plot (TP-2), its highest yield in 1988 was 3.06 dry tons and 23.72 fresh tons $\mathrm{ha}^{-1}$. It was considered as comparable to the standard value in Thailand, but not high at all considering the intensive treatments. Furthermore, after the first harvest, we could not do any more harvesting. Commercial plantation in more profitable condition found in the central plain of Thailand could harvest at least 3 crops in 3 years. Considering these situation, successful management of pineapple on the gravel tailings need more effort and research activity.

Total biomass of pineapple in TP-2 was highest, 13.1 tons ha- $\mathrm{a}^{-1}$ in 1988, and 50\% higher than that of cassava (TC-2), 9.58 tons ha-1 in 1988. Cropping periods of one and half year for pineapple and eight months for cassava, might be a reason for it. This relationship was true 
Table 4. Biomass of cassava from 1985 to 1990.

\begin{tabular}{|c|c|c|c|c|c|}
\hline $\begin{array}{l}\text { Plot } \\
\text { Part }\end{array}$ & Jan.'86 & Feb.'87 & Jan.' 88 & Jan.'89 & Jan.' 90 \\
\hline \multicolumn{6}{|l|}{ TC-0 } \\
\hline Leaf & 0 & 0 & 0 & 0 & 0 \\
\hline Stem & 0 & 0 & 0 & 0.004 & 0 \\
\hline Tuber & 0 & 0 & 0 & 0 & 0 \\
\hline Stick & 0 & 0 & 0 & 0.042 & 0 \\
\hline Total & 0 & 0 & 0 & 0.046 & 0 \\
\hline \multicolumn{6}{|l|}{ TC-0m } \\
\hline Leaf & - & 0.002 & 0.024 & 0.007 & 0.008 \\
\hline Stem & - & 0.080 & 0.232 & 0.215 & 0.302 \\
\hline Tuber & - & 0.417 & 0.960 & 0.976 & 0.654 \\
\hline Stick & - & 0.259 & 0.252 & 0.333 & 0.566 \\
\hline Total & - & 0.758 & 1.468 & 1.531 & 1.530 \\
\hline \multicolumn{6}{|l|}{ TC-1 } \\
\hline Leaf & $0.080(0.017)$ & 0.056 & 0.344 & 0.079 & 0.060 \\
\hline Stem & $8.332(2.600)$ & 0.364 & 1.368 & 2.081 & 1.192 \\
\hline Tuber & $11.044(3.069)$ & 0.720 & 2.520 & 4.756 & 2.602 \\
\hline Stick & - & 0.468 & 0.696 & 0.811 & 0.716 \\
\hline Total & 19.456 & 1.608 & 4.928 & 7.726 & 4.570 \\
\hline \multicolumn{6}{|l|}{ TC-2 } \\
\hline Leaf & $0.068(0.014)$ & 0.044 & 0.204 & 0.020 & 0.036 \\
\hline Stem & $10.456(3.262)$ & 0.608 & 3.076 & 1.936 & 1.626 \\
\hline Tuber & $21.208(5.896)$ & 3.148 & 5.588 & 7.344 & 4.857 \\
\hline Stick & - & 0.700 & 0.716 & 0.803 & 1.105 \\
\hline Total & 31.732 & 4.500 & 9.584 & 10.104 & 7.624 \\
\hline \multicolumn{6}{|l|}{ TC-3 } \\
\hline Leaf & $0.056(0.012)$ & 0.020 & 0.124 & 0.047 & 0.020 \\
\hline Stem & $6.776(2.114)$ & 0.280 & 1.380 & 0.882 & 0.882 \\
\hline Tuber & $8.832(2.455)$ & 1.688 & 3.312 & 3.281 & 3.200 \\
\hline Stick & - & 0.432 & 0.580 & 0.645 & 0.684 \\
\hline Total & 15.664 & 2.420 & 5.396 & 4.855 & 4.786 \\
\hline
\end{tabular}

(tons/ha, oven-dried basis)

-: no data

Figures in parentheses represent the calculated values into oven-dried weight

for the other plots with the same soil treatments, namely, between TC-1 and TP-1, TC-3 and TP-3.

Combination of mulching and chemical fertilizer (TP-3) produced approximately 50\% more biomass of pineapple (as well as crop yield) than that of compost and chemical fertilizer (TP-1). This was not true for cassava, namely, these two treatments seemed to be equivalent in yield. Response to the treatments between pineapple and cassava can be explained by their root distribution. Pineapple roots are concentrated on the surface soil near the mulching materials, whereas, cassava root develops more deeper in the solum. Pineapple roots, therefore, could receive more profitable effect from mulching since the prosperous roots are concentrated just below mulching. Another possible cause may be that cassava roots suffer from the over-wetting condition in the rainy season, which often spoils the quality of root. In this sense, mulching treatment as water holding material would not contribute more than as ion exchanger, especially for cassava. 
Table 5. Biomass of pineapple from 1986 to 1988.

\begin{tabular}{|c|c|c|c|c|}
\hline $\begin{array}{l}\text { Plot } \\
\text { Part }\end{array}$ & \multicolumn{2}{|c|}{ Oct.'86 } & \multicolumn{2}{|l|}{ Oct.'88 } \\
\hline \multicolumn{5}{|l|}{ TP-0 } \\
\hline Fruit & 0 & $0.080^{*}$ & 0.052 & $0.320^{*}$ \\
\hline Stalk & 0 & & 0.016 & \\
\hline Crown & 0 & & 0.084 & \\
\hline Leaf+stem & - & & 1.028 & \\
\hline Root & - & & 0.536 & \\
\hline Total & 0 & & 1.716 & \\
\hline \multicolumn{5}{|l|}{ TP-1 } \\
\hline Fruit & 0.408 & $2.808^{*}$ & 1.380 & $10.724^{*}$ \\
\hline Stalk & 0.396 & & 0.164 & \\
\hline Crown & 0.156 & & 0.640 & \\
\hline Leaf+stem & - & & 2.876 & \\
\hline Root & - & & 0.992 & \\
\hline Total & 0.960 & & 6.052 & \\
\hline \multicolumn{5}{|l|}{ TP-2 } \\
\hline Fruit & 1.428 & $15.357^{*}$ & 3.056 & $23.716^{*}$ \\
\hline Stalk & 0.944 & & 0.272 & \\
\hline Crown & 0.596 & & 0.780 & \\
\hline Leaf+stem & - & & 7.668 & \\
\hline Root & - & & 1.164 & \\
\hline Total & 2.968 & & 13.140 & \\
\hline \multicolumn{5}{|l|}{ TP-3 } \\
\hline Fruit & 0.748 & $5.158^{*}$ & 1.876 & $16.180^{*}$ \\
\hline Stalk & 0.152 & & 0.180 & \\
\hline Crown & 0.272 & & 0.736 & \\
\hline Leaf+stem & - & & 4.792 & \\
\hline Root & - & & 1.812 & \\
\hline Total & 1.172 & & 9.396 & \\
\hline \multicolumn{5}{|l|}{ TE-5 } \\
\hline Fruit & 0.072 & $0.628^{*}$ & 0.248 & $2.008^{*}$ \\
\hline Stalk & 0.044 & & 0.020 & \\
\hline Crown & 0.028 & & 0.088 & \\
\hline Leaf+stem & - & & 0.608 & \\
\hline Root & - & & 0.664 & \\
\hline Total & 0.144 & & 1.628 & \\
\hline
\end{tabular}

(tons/ha, oven-dried basis)

-: no data ${ }^{*}$ : fresh weight

\section{Chlorophyll Content}

Chlorophyll and nitrogen content of leaves has been studied especially for the appropriate fertilization to rice plant (Youn \& Ota, 1973). Unfortunately, adaptability of this relationship to cassava has not been clarified yet, and upon this, we tried to evaluate chlorophyll content of cassava leaves using chlorophyll meter (SPAD 501).

Chlorophyll meter, SPAD 501, was devised in 1983 by Soil and Plant Analyzer Development. Some researchers have exemplified the linear relationship between reading of the meter and nitrogen content in leaves of rice plant (Tyubachi et al. 1986; Kitagawa et al. 1987). In addition, both have been found to be higher in the vegetative stage than in the productive stage (Kitagawa et al, 1987). Furthermore, the linear relationship was confirmed between readings and the actual content of chlorophyll (M. Ueno, 1990), where regression equation was different among cultivars of rice plant.

Measurement was conducted for seemingly active cassava leaves ( 24 weeks after planting) in 1985, 1987 , 1988, and 1989. Since chlorophyll content was reported to be fluctuated with the growing stage of rice plant, growth and development of cassava will be reviewed briefly according to ElSharkawy \& Cook (1987); During the first few weeks of crop establishment,

the plants form a fibrous root system, mainly in the upper layer $(1 \mathrm{~m})$ of soil. About 2 to 3 months after planting, some of the fibrous roots (from 5-15 roots per plant) start to expand rapidly, forming storage roots for starch. The formation of leaves in cassava has preference for available assimilates over storage roots in the first 3 months of growth. However, after this period, cassava continues to form new leaves concurrently with storage root filling. The leaf area index (LAI), leaf area per ground unit area, increases in the first 3 to 6 months and then declines gradually as the older leaves in the lower strata of the canopy fall.

Taking this into consideration, the ages of the leaves when examined ( 24 weeks) were generally at the maximum LAI stage when root filling has already started. Thus, chlorophyll 
Table 6. Result of Duncan's multiple range test for the readings of chlorophyll meter of cassava leaves. Upper: plot name. Lower: mean values of the readings of chlorophyll meter.

\begin{tabular}{cccccc}
\hline $\begin{array}{l}\text { Year/age } \\
\text { (Replication) }\end{array}$ & \multicolumn{5}{l}{$\begin{array}{l}\text { Plot name and } \\
\text { Readings of chlorophyll meter }\end{array}$} \\
\hline $1985 / 24 \mathrm{w}$ & TC-0 & TC-3 & TC-1 & TC-2 & \\
$(\mathrm{n}=70)$ & $21.2^{\mathrm{a}}$ & $22.7^{\mathrm{b}}$ & $35.2^{\mathrm{C}}$ & $37.5^{\mathrm{d}}$ & \\
$1987 / 24 \mathrm{w}$ & TC-0 & TC-0m & TC-3 & TC-2 & TC-1 \\
$(\mathrm{n}=55)$ & $24.9^{\mathrm{a}}$ & $27.4^{\mathrm{b}}$ & $42.3^{\mathrm{C}}$ & $47.1^{\mathrm{d}}$ & $49.9^{\mathrm{e}}$ \\
$1988 / 24 \mathrm{w}$ & TC-0 & TC-0m & TC-1 & TC-3 & TC-2 \\
$(\mathrm{n}=20)$ & $19.8^{\mathrm{a}}$ & $26.4^{\mathrm{b}}$ & $33.2^{\mathrm{C}}$ & $33.2^{\mathrm{C}}$ & $36.2^{\mathrm{d}}$ \\
$1989 / 24 \mathrm{w}$ & TC-0 & TC-0m & TC-3 & TC-1 & TC-2 \\
$(\mathrm{n}=20)$ & $25.5^{\mathrm{a}}$ & $30.6^{\mathrm{b}}$ & $34.1^{\mathrm{C}}$ & $35.8^{\mathrm{C}}$ & $41.9^{\mathrm{d}}$ \\
\hline
\end{tabular}

content of leaves would be reflected on the yield and biomass. Results of measurement were summarized in Table 6, together with the result of Duncan's new multiple range test. Simple correlation analysis during 1987 to 1989 was conducted, excluding the data in 1985 because no data were available on crop yield and total biomass on oven-dried basis. Correlation coefficients of 0.75 and 0.67 were obtained between readings of chlorophyll meter and total biomass and also between readings and crop yield, respectively. These values are not significantly high, but could be used as an index to predict the yield. Research activity including the examination on a optimal timing of measurement merit further attention since this measurement is very simple and considered to be valuable for practical manipulation of tropical crops through an appropriate and direct countermeasure.

\section{Economical Aspect}

Economical aspect is very important even for sustainable agriculture. In that sense, intensive treatments are equivalent to the money consuming practice. In Table 1, treatment cost, maximum yield during this experiment, and calculated maximum income using average farm price from 1980 to 1989 are included. For.cassava, farm price fluctuated significantly within these 10 years, from 0.40 to $0.89 \mathrm{Bahts} / \mathrm{kg}$ (Office of Agricultural Economics, 1990). That is also true for pineapple, i.e., 0.91 to $1.98 \mathrm{Bahts} / \mathrm{kg}$. Taking these values into consideration, the calculated maximum income is much less than the investment for cassava. However, pineapple cultivation using mulching and chemical fertilizer (TP-3) would be more promising, if farmers can collect mulching materials by themselves. Mulching materials such as Imperata grass can be collected easily from the local abandoned area. At the same time, this practice can be considered as weeding, which will supply further land for agriculture. Besides, in our experiment, the amount of mulching materials was too much to apply routinely (36 tons ha-1). This amounted to 9 times greater than that adopted by Lal (1974), who used 4 tons ha-1 of rice straw for mulching. Thus, quantitative evaluation of the amount of mulching on crop yield should be further studied. It will make it possible to think out a more profitable way to agriculture in Takuapa.

ACKNOWLEDGMENTS The authors are grateful to the organizers of the agroforestry research project, of which the present research was a part, and to the Ministry of Education, Science and Culture of Japan for funding (59041056, 60041063, 62041088, 63041110). They wish to express their most sincere thanks to all the members of Waste Land Project 
(WLP, appeared on the running title) who cooperated with them throughout the project period, particularly to Dr. M. Kanzaki, Osaka City University, Japan, and Drs. P. Sahunalu and P. Danmanonda, Kasetsart University, Thailand.

\section{REFERENCES}

Bartholomew, D. P. \& Kadzimin, S. B. 1977. 5. Pineapple. In Alvim, Paulo de T. \& Kozlowski, T. T. (eds.), Ecophysiology of Tropical Crops, 113-157. Academic Press, Inc. New York.

El-Sharkawy, M. A. \& Cock, J. M. 1987. Response of cassava to water stress. Plant and Soil 100: $345-360$.

Kanzaki, M. Improvement of biological productivity in degraded lands in Thailand - Growth of Eucalyptus camaldulensis and effects of the treatments. (In prep.).

Kitagawa, Y., Okayama, K. \& Hirokawa, T. 1987. Determination of leaf color in rice plant, "KOSHIHIKARI" with a chlorophyll meter. Bull. Toyama Agric. Res. Center 1: 1-7. (In Japanese with English summary)

Lal, R. 1974. Soil temperature, soil moisture and maize yield from mulched and unmulched tropical soils. Plant and Soil 40: 129-143.

Office of Agricultural Economics 1989. III. Food crops \& VI. Other crops. In Agricultural Statistics of Thailand - Crop Year 1988/89, 10-51 \& 80-98. Agricultural Economics Report No.14. (In Thai with figure leagends and tables in English)

Sahunalu, P. \& Anunsiriwat A. 1985. Some soil properties of tin mine spoiled land at the forestry student's training station in Bangmuang, Takuapa, Pangnga. Proceedings on the Seminar on Problems and Guidelines for Mine-spoiled Reclamation, Phuket, Thailand, November 8-11, 1985, 52-99. (In Thai with English summary)

Sakurai, K., Araki, S., Naganawa, T., Iwatsubo, G., Attanandana, T., \& Prachaiyo, B. 1989. Improvement of biological productivity in degraded lands in Thailand. I. Site and profile descriptions of the experimental sites. Pedologist 33: 17-29.

Sanchez, P. A. 1976. Properties and Management of Soils in the Tropics (Chapter 6. Nitrogen, 184-222). John Wiley and Sons. New York.

Syers, J. K. \& Springett, J. A. 1984. Earthworms and soil fertility. Plant and Soil 76: 93-104.

Tanpibal,V. \& Sahunalu, P. 1985. Species trials of some terrestrial plants on the tin mine spoil land. Proc. of the Seminar on Problems and Guidelines for Mine-spoil Reclamation, Phuket, Thailand, November 8-11. 1985, 184-197. (In Thai with English summary)

Tanpibal, V. \& Sahunalu, P. 1989. Characteristics and management of tin mine tailings in Thailand. Soil Technology 2: 17-26.

— \& Sakurai, K. 1991. Effect of the application of clayey materials, city compost, chemical fertilizer on the growth of Stylosanthes guianensis on the land after mining. (In prep.)

Thailand Development Research Institute 1987. Chapter 2 Land Resources. In Arbhabhirama, A., Phantumvanit, D., Elkington, J., \& Ingkasuwan, P. (eds.), Thailand Natural Resources Profile, 19-45. Sangdad Publications, Thailand.

Tyubachi, T., Asano, I., \& Oikawa, T. 1986. The diagnosis of nitrogen nutrition of rice plants (SASANISHIKI) using chlorophyll-meter. Jap. Jour. Soil Sci. Plant Nutr. 57: 190193. (In Japanese)

Ueno, M. 1990. Leaf color measurement. In Jap. Soc. Soil Sci. Plant Nutr. (ed.), Experimental Methods for Plant Nutrition, 362-367. Hakuyusha, Tokyo. (In Japanese) 
Verapattananirund, P., Na Nagara, T., Tongyai, C., \& Nualla-ong, S. 1988. A promising lowinput management to sustain high cassava yield in Northeast Thailand. Paper Pesented at the International Symposium on Tropical Root Crops. October 30 - November 5, 1988. Bangkok, Thailand. $11 \mathrm{pp.}$

Youn, K. B. \& Ota, Y. 1973. Changes in the chlorophyll content and chlorophyll retention of leaf segments according to the growth of various leaf blades in rice plant. Proc. Crop Sci. Soc. Japan 42: 6-12. (In Japanese with English summary)

Received June 20, 1991

Accepted Oct. 13, 1991

桜井克年, B. PrachaIYo, T ATtANANDANA, V. TANPIBAL, 荒木 茂, 長縄貴彦, 岩坪五郎，依田恭二 タイの土壤劣化地における生物生産力の回復 II. タクアパ 実験地における植物の成長に対する土壤温度，湿度，肥沃度の影響

タイの半島部，特にパンガ県 (Phang-nga Province) にはスズ鉱山が多い。スズ鉱石を水で選別 した跡地には，粒径によって選別された粘土，砂，磷の放棄地が残る。放棄地での天然更新は大 変困難であり, 人為的な植生回復の試みがなされている。そこで本研究は「放棄地計画, Waste Land Project」(WLP) の一環として, パンガ県のタクアパ (Takuapa) の砂と礫の放棄地に扔い てEucalyptus camadulensis を劣化地の植生回復のために植樹し, 可能な農業の方法を示すために キャッサバとパイナップルを栽培した。

土地の改良策として耕起・化学肥料施肥 (1.67 ton/ha/yr) - City compost の施肥 (12.5 ton/ha/yr)・およびチガヤ Imperata cylindrica のワラ (16.7 ton/ha/yr) によるマルチング (地表 の被覆)を試みた。その中でマルチングが樹木にも作物にももっとも良い方法であった。その理 由としては, i) 最も暑い季節において土壌の最高温度を下げる, ii) 一年中よい土埪水分条件を 保つ, iii) マルチング材料そのものが植物に栄養源として利用され，また土壤微生物の生物的活 動を活発化する，iv）さらに現場で雑草を集めることによって容易に実行できることが挙げら れる。

不毛地の回復に関する限りは, チガヤによるマルチングと組み合わせた Eucalyptus camadulensis の植栽がもっとも見込みの高い方法である。一方, 実際的な農業方法の確立, 少なくとも 持続的にキャッサバとパイナップルの収穫を得ることを，ここのようなごく筫弱な土埪で実現す るためには，さらなる努力が不可欠である。 